\title{
Filsafat Pancasila Soekarno sebagai Paradigma Pembangunan Manusia Seutuhnya
}

\author{
Ahmad Rifai \\ Universitas Peradaban \\ ahmad_rifaizen@peradaban.ac.id
}

\begin{abstract}
ABSTRAK
Penelitian ini dimaksudkan untuk menggali dan menganalisis filsafat Pancasila oleh Soekarno sebagai paradigma pembangunan manusia Indonesia seutuhnya. Penelitian ini merupakan penelitian dengan menggunakan metode kualitatif melalui kajian kepustakaan. Sedangkan pendekatan yang digunakan dalam penelitian ini adalah pendekatan filosofis dengan menggunakan alat analisis metodis berupa kesinambungan historis, interpretasi dan heuristik atau penemuan baru. Adapun sumber primer yang digunakan adalah pemikiran-pemikiran filsafat Pancasila oleh Soekarno yang digunakan untuk membedah konsep pembangunan manusia seutuhnya. Penelitian ini menyimpulkan bahwa landasan utama konsep pembangunan manusia Indonesia adalah pembangunan sumber daya manusia yang berkualitas, dan kemampuan ilmu pengetahuan dan teknologi yang dalam pengaplikasiannya diperlukan langkah konkret yang memiliki kesesuaian dengan falsafah negara, yaitu Pancasila. Kedua, Pembangunan manusia Indonesia menganut konsep pembangunan manusia seutuhnya yang berfokus pada peningkatan kualitas hidup penduduk baik secara fisik, mental maupun spiritual untuk kesejahteraan rakyat Indonesia dalam seluruh aspek kehidupannya. Ketiga, konsep pembangunan manusia Indonesia dalam perspektif filsafat Pancasila oleh Soekarno dimaknai sebagai pembangunan yang tidak sekedar menekankan pada aspek kebersamaan, kekeluargaan, dan gotong royong belaka, akan tetapi juga pembangunan pada aspek religiusitas.
\end{abstract}

Kata Kunci: Filsafat Pancasila, Pembangunan Manusia, Soekarno. 


\begin{abstract}
This research is intended to explore and analyze the Pancasila philosophy by Soekarno as a paradigm for the development of the whole Indonesian human being. This research is a research using qualitative methods through literature review. While the approach used in this research is a philosophical approach using methodical analysis tools in the form of historical continuity, interpretation and heuristics or new discoveries. The primary sources used are the philosophical thoughts of Pancasila by Soekarno which are used to dissect the concept of whole human development. This study concludes that the main foundation of the concept of Indonesian human development is the development of quality human resources, and the ability of science and technology, which requires concrete steps to be applied in accordance with the state philosophy, namely Pancasila. Second, Indonesia's human development adheres to the concept of complete human development which focuses on improving the quality of life of the population, physically, mentally and spiritually for the welfare of the Indonesian people in all aspects of their lives. Third, the concept of Indonesian human development in the perspective of the Pancasila philosophy by Soekarno was interpreted as development that not only emphasized the aspects of togetherness, kinship, and mutual cooperation, but also development on the aspect of religiosity.
\end{abstract}

Keywords: Pancasila Philosophy, Human Development, Soekarno.

\section{PENDAHULUAN}

Ukuran kualitas Sumber

Daya Manusia (SDM) sesungguhnya

adalah muara dariproses-proses

pembangunan dalam segala bidang.

Konsepsi pembangunan terbaru

adalah meletakkan manusia sebagai

pusat perhatian. Konsep ini

memperhatikan bahwa manusia perlu

menyadari potensinya untuk

meningkatkan pilihan-pilihan untuk membawa kehidupannya lebih

bernilai (UNDP, 2009). Untuk itu setiap negara perlu menyusun kebijakan yang menjamin kesejahteraan yang lebih baik dengan cara memperbaiki lingkungan, serta menjauhkan manusia dari konflik dan kerusakan lingkungan.

Hakikat dasar ontologi Pancasila adalah manusia, karena manusia merupakan subjek hukum 
pokok sila-sila yang ada dalam Pancasila. Pancasila sebagai dasar filsafat negara Republik Indonesia memiliki susunan lima sila yang mempunyai sifat dasar kesatuan yang mutlakdengan sifat kodrat monodualis yaitu sebagai makhluk individu sekaligus juga sebagai makhluk sosial, serta kedudukannya sebagai makhluk pribadi yang berdiri sendiri dan sekaligus juga sebagai makhluk Tuhan. Konsekuensi dari dijadikannya Pancasila sebagai dasar negara Indonesia adalah bahwa segala aspek dalam penyelenggaraan negara diliputi oleh nilai-nilai Pancasila yang merupakan kodrat manusia yang monodualis (Dewantara, 2017:11).

Oleh karena itu, nilai-nilai Pancasila sebagai falsafah hidup bangsa perlu diimplementasikan untuk membangkitkan semangat juang bangsa. Semangat juang itu bukan saja untuk menyelesaikan permasalahan keterpurukan ekonomi, tetapi juga untuk meningkatkan kualitas Sumber Daya Manusia Indonesia. Kualitas itu akan lahir dari manusia yang berkarakter religius, percaya diri, dan memiliki etos kerja yang tinggi (Poespowardojo dan Hardjatno, 2010: 30). SDM berkualitas inilah yang akan menyusun konsep-konsep kebijakan pembangunan dan menjalankan penyelenggaraan negara yang lebih berorientasi kepada kesejahteraan dalam rangka peningkatan harkat bangsa sebagai manusia (Poespowardojo, 2010:35).

\section{PEMBAHASAN}

Pembahasan mengenai manusia dalam kerangka filsafat Pancasila merupakan hal yang 
penting dan sentral. Fenomenologi pada dasarnya melihat dan memandang segala bentuk fenomena yang menghadirkan fenomena tersebut dalam dunia, terlebih dalam dunia kesadaran. Fenomena berasal dari bahasa Yunani yaitu "phainomenon" yang artinya "apa yang terlihat, sedangkan dalam kamus bahasa Indonesia bisa diartikan sebagai, gejala alam, serta kejadian-kejadian yang dapat di rasakan dan dilihat dengan panca indera. Hal ini memberikan arti bahwa fenomena adalah sesuatu yang dapat dilihat, diamati, dan dimaknai sebagai bagian dari kehidupan manusia (Rorong, 2020:

3). Dalam kerangka ilmu fenomenologi dapat dijelaskan bahwa kelima sila dalam Pancasila secara etis mengikat setiap manusia Indonesia untuk mematuhinya. Hal tersebut harus dijadikan sebagai pijakan utama dalam melakukan pemikiran reflektif mengenai rumusan Pancasila secara filosofis yang dikembangkan oleh Soekarno, terutama dalam konteks pembangunan manusia Indonesia.

\section{Manusia yang Berpersatuan}

Dalam menjelaskan konsep persatuan, Soekarno mengutip pendapat $\mathrm{Ki}$ Bagoes Hadikoesoemo, seorang pemikir Islam di Indonesia. Menurut Ki Bagoes, kebangsaan lahir dari 'persatuan antara orang dan tempat'. Oleh karena itu Soekarno mengatakan:

"Kemarin, kalau tidak salah, saudara $\mathrm{Ki}$ Bagoes Hadikoesoemo,... mengatakan tentang "Persatuan antara orang dan tempat". Persatuan antara orang dan tempat tuantuan sekalian, persatuan antara manusia dan 
tempatnya! Orang dan tempat tidak dapat dipisahkan! Tidak dapat dipisahkan rakyat dari bumi yang ada di bawah kakinya... bumi yang didiami manusia itu.

Apakah tempat itu? tempat itu yaitu tanah air. Tanah air itu adalah satu kesatuan. Allah SWT. membuat peta dunia, menyusun peta dunia. Kalau kita melihat peta dunia, kita dapat menunjukkan di mana "kesatuan-kesatuan" di situ. Seorang anak kecil pun, jikalau ia melihat peta dunia, ia dapat menunjukkan bahwa Kepulauan Indonesia merupakan satu kesatuan... Kesatuan bumi Indonesia dari ujung Sumatra sampai ke Irian (Rahardjo, 2001: 2001).

\section{Soekarno beranggapan}

bahwa kebangsaan itu lahir karena tiga hal, yaitu kehendak untuk bersatu, persamaan karakter karena persamaan nasib, dan kaitan antara tempat (Tanah Air) dan penduduk yang mendiaminya. Ketiga hal tersebut sudah ada dan sudah bermanifestasi di zaman itu.
Semua rakyat saat itu sudah memiliki kehendak untuk menyatukan diri mereka dalam membangun "Bangsa Indonesia"; semua rakyat saat itu memiliki persamaan nasib yaitu nasib jadi rakyat yang terjajah; semua rakyat saat itu memiliki persamaan karakter yaitu karakter terjajah; dan semua rakyat saat itu sudah mendiami bumi Indonesia dari ujung Sumatera hingga ujung Papua (Irian), maka menurut Soekarno, sudah semestinyalah rakyat Indonesia mengklaim bahwa sudah memiliki kebangsaan, yaitu kebangsaan Indonesia.

Selain itu, Soekarno pun menegaskan bahwa jika prinsip "Kebangsaan" ini dimasukkan 
ke dalam Pancasila dan

dijalankan secara penuh

kesadaran oleh semua rakyat

Indonesia, maka negara

Indonesia yang akan dibangun

oleh Bangsa Indonesia akan kuat

dan tidak gampang hancur.

Soekarno mengatakan:

“... Negara jikalau didasarkan antara lain atas rasa kebangsaan, negara demikian itulah kuat. Maka oleh karena itu kita dengan sengaja memasukkan sila Kebangsaan di dalam Pancasila kita... untuk negara yang kuat kita mesti mendasarkan negara itu atas kebangsaan" 2016:178-179).

Soekarno

benar-benar

menginginkan sebuah negara

yang kuat, bersatu dan

berkemajuan berdasarkan

semangat kebangsaan.

1. Manusia

Berperikemanusiaan

yang

Pidato Soekarno saat

sidang perumusan Pancasila (1
Juni 1945), Soekarno tidak

menggunakan kata

"kemanusiaan yang adil dan

beradab", tetapi menggunakan

kata "perikemanusiaan". Apa

yang dimaksud Soekarno dengan

kata

“perikemanusiaan"?

Soekarno sendiri yang

menjelaskan:

“... prinsip kebangsaan ini ada bahayanya!

Bahayanya ialah mungkin orang meruncingkan

nasionalisme menjadi chauvinisme, sehingga berpaham "Indonesia uber Alles". Inilah bahayanya. Kita cinta tanah air yang satu, merasa berbangsa yang satu, mempunyai bahasa yang satu. Tetapi tanah air kita Indonesia hanya satu bagian kecil saja daripada dunia! Ingatlah akan hal ini! Gandhi berkata: "Saya seorang nasionalis, tetapi kebangsaan saya adalah perikemanusiaan", "My nationalism is humanity..." kita harus menuju persatuan dunia, persaudaraan dunia. 
Kita bukan saja harus mendirikan negara Indonesia merdeka, tetapi kita harus menuju pula kepada kekeluargaan bangsa-bangsa.... Inilah filosofisch principe yang nomor dua, yang saya usulkan kepada tuan-tuan, yang boleh saya namakan "internasionalisme".

..Internasionalisme tidak dapat hidup subur kalau tidak berakar di dalam buminya nasionalisme. Nasionalisme tidak dapat hidup subur, kalau tidak hidup dalam tamansarinya internasionalisme... Jadi, dua hal ini,... adalah bergandengan erat satu sama lain (Rahardjo, 2001:30-31).

Selanjutnya, Soekarno

juga menegaskan bahwa:

"Kebangsaan yang kita anjurkan bukan kebangsaan yang menyendiri, bukan chauvinisme, sebagai dikobar-kobarkan orang di Eropa, yang mengatakan "Deutschlandüber Alles" tidak ada setinggi Jermania yang katanya bangsanya minulyo, berambut jagung dan bermata biru..." (Sekretariat Negara Republik Indonesia, 1995:76)
Pernyataan dari Soekarno

itu bertujuan untuk

menunjukkan bahwa prinsip

kebangsaan yang dianut Bangsa

Indonesia (pada prinsip pertama)

bukanlah berkiblat pada gagasan

Hitler tentang superioritas

bangsa Jerman. Memang bangsa

Indonesia harus bangga

berkebangsaan Indonesia, tetapi

hal itu tidak lantas menjadikan

manusia Indonesia merasa di

atas bangsa yang lain. Berangkat

dari simbol inilah Soekarno

memperkenalkan prinsip yang

kedua, yakni internasionalisme

atau perikemanusiaan. Soekarno

berpendapat bahwa rasa

kebangsaan hanya dapat tumbuh

jika ada dalam rasa persaudaraan

dengan bangsa-bangsa lain. 
Kemanusiaan yang adil

dan beradab mencerminkan sifat

hakiki manusia sebagai makhluk

sosial (homo socius).

Kemanusiaan berasal dari kata

manusia, yang merupakan

makhluk ciptaan Tuhan Yang

Maha Esa. Adapun nilai-nilai

yang terkandung dalam sila

kemanusiaan yang adil dan

beradab adalah sebagai berikut:

a) Mengakui dan menghargai manusia sesuai dengan harkat dan martabatnya sebagai makhluk Tuhan Yang Maha Esa.

b) Mengakui

persamaan

derajat, persamaan hak dan

kewajiban tanpa membeda-

bedakan agama dan

kepercayaan, suku, ras,

keturunan, adat, status sosial, warna kulit, jenis

kelamin, dan lain

sebagainya.

c) Mengembangkan sikap

saling mencintai sesama

manusia. Mengembangkan

sikap tenggang rasa (tepo

seliro).

d) Mengembangkan sikap

tidak semena-mena terhadap

orang lain.

e) Menjunjung tinggi nilainilai kemanusiaan.

f) Gemar melakukan kegiatan kemanusiaan.

g) Berani membela kebenaran dan keadilan dengan penuh kejujuran (Rahayu, 2019: $300)$.

Kesimpulannya,

kemanusiaan atau

"internasionalisme" yang 
dimaksud oleh Soekarno adalah

persatuan dunia, persaudaraan

dunia, dan kekeluargaan bangsa-

bangsa. Kesadaran itu

menegaskan bahwa meski pun

dibatasi oleh wilayah

kenegaraan yang berbeda-beda,

manusia tetap merupakan satu

"keluarga", dalam keluarga

bangsa-bangsa. Selain itu,

kemanusiaan menurut Soekarno

mengetengahkan bahwa walau

terpisah oleh wilayah

kenegaraannya, manusia tetap

bersaudara dan karenanya wajib

untuk bersatu dalam persatuan

global dan persatuan universal.

Lebih lanjut, Soekarno

menjelaskan lebih panjang lebar

mengenai "Sila

Perikemanusiaan" dalam

makalahnya untuk kursus
Pancasila tanggal 5 Juli 1958 di

istana negara :

“... Perikemanusiaan adalah jiwa yang merasakan bahwa antara manusia dengan lain manusia adalah hubungannya, jiwa yang hendak mengangkat membedakan jiwa manusia itu lebih tinggi daripada jiwa binatang.... Jikalau kita berbuat sesuatu yang rendah yang membikin celaka kepadamanusia lain, kita berkata kita melanggar perikemanusiaan, kita melanggar hukum menseljkheid.

... Kita tidak menghendaki supaya nasionalisme kita menjadi nasionalisme yang chauvinis, tapi nasionalisme yang hidup di dalam suasana perikemanusiaan:

nasionalisme yang mencari agar segala umat manusia ini akhirnya nanti hidup dalam satu keluarga besar yang sama bahagianya".

Kesimpulannya,

"kemanusiaan yang adil dan beradab" yang dimaksud oleh Soekarno adalah kesadaran bahwa manusia memiliki jiwa yang merasakan hubungan antara manusia yang satu dengan 
manusia yang lain. Apabila

seseorang mencelakakan

manusia lain, maka dia sudah

melanggar jiwa kemanusiaan

tadi. Karena itu, kemanusiaan

menjadikan seseorang selalu

"beradab" sebagaimana

disebutkan dalam KBBI beradab

memiliki arti yaitu mempunyai

adab; mempunyai budi bahasa

yang baik; berlaku sopan,

Kemanusiaan juga harus "adil"

yaitu berarti sama berat, tidak

berat sebelah, dalam artian,

kemanusiaan menjadikan

manusia Indonesia berupaya

untuk hidup dalam satu

"keluarga besar manusia" yang

"sama bahagianya"; "sama

makmurnya", "sama

sejahteranya"; bukan "keluarga

besar manusia" yang berbeda

makmurnya, berbeda rejekinya, tidak adil kesejahteraannya, tidak adil bahagianya (Hidayat, 2018: 9).

Pancasila menunjukkan

bentuk dari kemanusiaan dalam sila kedua yang menempatkan manusia sebagai tujuan utama seperti dijelaskan dalam sila keadilan sosial dan sila persatuan Indonesia sehingga mampu mewujudkan keadilan dan kemanusiaan yang sempurna. Sedangkan upaya perwujudannya tertuang dalam sila kerakyatan sebagai mekanisme politik untuk mencapai tujuan dimaksud.

Yang dimaksud Soekarno dengan prinsip "Keadilan Sosial" adalah keadilan ekonomis atau kesejahteraan ekonomis atau 
persamaan di dalam lapangan

ekonomi yang hanya dapat

dicapai lewat sistem sosialisme

ala Indonesia yang disebutnya

sebagai "Sosialisme Pancasila".

Pada saat sidang perumusan

Pancasila tanggal 1 Juni 1945

Soekarno mengatakan:

"Prinsip nomor empat sekarang saya usulkan. Saya di dalam 3 hari ini belummendengarkan prinsip itu, yaitu "prinsip kesejahteraan", "prinsip: tidak akan adakemiskinan di dalam Indonesia Merdeka"... Apakah kita mau Indonesia Merdeka yang kaum kapitalisnya merajalela, ataukah yang semua rakyatnya sejahtera, yang semuaorang cukup makan, cukup pakaian, hidup dalam kesejahteraan, merasa dipangku oleh Ibu Pertiwi yang cukup memberi sandang pangan kepadanya?

Mana yang kita pilih, Saudara-saudara? Jangan Saudara kira, bahwa kalau Badan Perwakilan Rakyat sudah ada, kita dengan sendirinya mencapai kesejahteraan ini.Kita sudah lihat, di negara-negara Eropa adalah Badan Perwakilan, adalah parlementaire democratie. Tapi tidaklah di Eropa justru kaum kapitalis merajalela?...

Tak lain dan tak bukan sebabnya, ialah oleh karena badan-badan perwakilan rakyatyang diadakan di sana itu, sekadar menurut resepnya

FranscheRevolutie. Tak lain tak bukan adalah yang dinamakan democratie di sana itu ialah politiekedemocratie saja;semata-mata tidak ada

socialerechtvaardigheid, tak ada keadilan sosial, tidak

adaekonomischedemocra tie sama sekali...

Adakah keadaan yang demikian ini yang kita kehendaki? Saudarasaudara, saya usulkan: Kalau kita mencari demokrasi hendaknya bukan demokrasi Barat, tetapi permusyawaratan yang memberi hidup, yakni politik economische democratie yang mampu mendatangkan

kesejahteraan sosial! Rakyat Indonesia sudah lama bicara tentang hal ini.

Apakah yang dimaksud dengan Ratu Adil? Ialah social rechtvaardigheid. 
Rakyat ingin sejahtera. Rakyat yang tadinya merasa dirinya kurang makan, kurang pakaian, menciptakan dunia baru yang di dalamnya ada keadilan, di bawah pimpinan Ratu Adil.

Maka oleh karena itu, jikalau kita memang betul-betul mengerti, mengingat, mencintai rakyat Indonesia, marilah kita terima prinsip hal socialrechtvaardigheid ini, yaitu bukan saja bersamaan politik, Saudara-saudara, tetapi pun di atas lapangan ekonomi kita harus mengadakan persamaan, artinya kesejahteraan bersama yang sebaikbaiknya" (Alam, 2001: 25-27).

Demikianlah cita-cita Soekarno

untuk menciptakan masyarakat

Indonesia yang berkeadilan

tanpa membeda-bedakan suku, agama dan ras apapun di antara sesama anak bangsa..
2. Manusia

Berkesejahteraan

Soekarno menggunakan

simbolisme Ratu Adil dalam

menjelaskan prinsip negara

tentang kesejahteraan sosial.

Soekarno mengatakan:

"Apakah yang dimaksud dengan Ratu Adil? Yang dimaksud dengan faham Ratu Adil ialah socialerechtvaardigheid, rakyat ingin sejahtera. Rakyat yang tadinya merasa dirinya kurang makan kurang pakaian, menciptakan dunia baru yang di dalamnya ada keadilan, di bawah pimpinan Ratu Adil" (Sekretariat Negara Republik Indonesia, 1995:79).

Dalam alam pikiran masyarakat Indonesia, khususnya Jawa, Ratu Adil adalah simbol tentang adanya kemakmuran yang dibawa oleh seorang terpilih. Ratu Adil seakan menjadi janji mesianis yang khas dimiliki oleh manusia 
Indonesia. Di bawah kepemimpinan Sang Ratu Adil inilah akan datang kesejahteraan, kemakmuran, dan kelimpahan bersama di segala bidang. Kesejahteraan bersama inilah yang hendak digagas Soekarno dengan penggunaan simbolisme Ratu Adil. Prinsip kesejahteraan sosial yang diidamkan bersama haruslah diciptakan oleh prinsip demokrasi yang telah diutarakan sebelumnya. Dalam alam kemerdekaan dicita-citakan bersama inilah Ratu Adil akan datang (Dewantara, 2017:58).

Konsep kesejahteraan ini erat kaitannya dengan konsep "kerakyatan" yang ditawarkan oleh Soekarno. Dalam pidato saat merumuskan Pancasila di sidang BPUPKI (tanggal 1 Juni 1945), Soekarno tidak menyebut sila ini dengan redaksi yang sekarang dikenal. Soekarno hanya menyebut sila ini dengan sebutan pendek, yaitu "dasar mufakat" atau "dasar demokrasi”. Soekarno mengatakan:

“... Apakah dasar yang ke3? Dasar itu ialah mufakat, dasar perwakilan, dasar permusyawaratan. Negara Indonesia bukan satu negara untuk satu orang, bukan satunegara untuk satu golongan walaupun golongan kaya. Tetapi kita mendirikan negara"semua buat semua", "satu buat semua, semua buat satu"...Dengan cara mufakat, kita perbaiki segala hal..., yaitu dengan jalan pembicaraan ataupermusyawaratan di dalam Badan Perwakilan Rakyat.Apa-apa yang belum memuaskan, kita bicarakan di dalam permusyawaratan. Badan perwakilan, inilah tempat kita untuk mengemukakan tuntutantuntutan... Di sinilah kita usulkan kepada pemimpin- 
pemimpin rakyat, apa-apa yang kita rasa perlu bagi perbaikan" (Rahardjo, 2001:31).

Selain itu, Soekarno juga mempertegas keterkaitan antara kesejahteraan dan kerakyatan yang merupakan perasan dari konsep socio democratie dalam pidato yang sama dengan mengatakan:

"Kalau kita mencari demokrasi, hendaknya bukan demokrasi Barat, tetapipermusyawaratan yang memberi hidup, yakni politiekecomische democratieyang mampu mendatangkan kesejahteraan sosial... Maka oleh karena itu,jikalau kita memang betul-betul mengerti, mengingat, mencintai rakyatIndonesia, marilah kita terima prinsip hal sociale rechtvaardigheid ini, yaitu bukan saja persamaan politik, saudara-saudara, tetapi pun di atas lapanganekonomi kita harus mengadakan persamaan, artinya kesejahteraan bersamayang sebaikbaiknya"(Rahardjo, 2001:35).

Hal tersebut di atas dirumuskan Soekarno bukan tanpa sebab. kesadaran bahwa kesenjangan kesejahteraan ekonomi masyarakat semakin terlihat dan menjadi fakta yang semakin tampak dan memenuhi kesadaran bersama. Karena itu, kesenjangan pemerataan keadilan dengan mendasarkan pada ide kesejahteraan sungguh merupakan problem yang harus segeradipecahkan bersama melalui konsep kerakyatan.

\section{Prinsip Filsafat}

Pancasila, sila ketuhanan menjadi pijakan dan sila kemanusiaan menjadi muara tujuan. Sila keadilan sosial ditempatkan sebelum sila kemanusiaan, karena sila tersebut mempraksiskan pemuliaan terhadap manusia dalam konteks keadilan sosial. 
Sebab, jika kemanusiaan adalah

bentuk (forma), keadilan sosial adalah isi (materia). Sementara itu, sila kerakyatan ditempatkan sebelum sila keadilan sosial karena sila tersebut menjadi mekanisme politik bagi perwujudan keadilan sosial. Hasilnya, upaya pemanusiaan melalui keadilansosial ini kemudian disempurnakan melalui pengadaban manusia dalam kerangka persatuan atas kemajemukan bangsa (sila ketiga) (Arif, 2016:26).

Pemahamanimplementasi

Pancasila sebagai pandangan hidup dan dasar negara dapat dijadikan pedoman dalam kehidupan bermasyarakat dan bernegara. Implementasi tersebut adalah (Srijanti, 2007:

67-68).

"Implementasi sila pertama, ketuhanan Yang Maha Esa, menghendaki setiap warga negara untuk menjunjung tinggi agama dan kepercayaan terhadap Tuhan. Diharapkan setiap warga negara memiliki keyakinan kepada Tuhan yang menciptakan manusia dan dunia serta isinya yang diwujudkan dengan memeluk agama serta kepercayaan kepada Tuhan. Pedoman yang harus dilaksanakan setiap warga negara adalah bahwa setiap warga negara percaya dan takwa kepada Tuhan YME sesuai dengan agama dan kepercayaan masing-masing menurut dasar kemanusiaan yang adil dan beradab, hormat-menghormati dan bekerja sama antara pemeluk agama dan penganut kepercayaanyang berbeda sehingga terbina kerukunan hidup, saling menghormati dan kebebasanmenjalankan ibadah sesuai dengan agama dan kepercayaannya, tidak memaksakansuatu agama dan kepercayaan kepada orang lain.

Implementasi sila kedua, kemanusiaan yang adil dan beradab, menghendaki sesama manusia tidak saling 
melecehkan, sesama
manusia punya rasa
memiliki, setiap manusia
menjaga keseimbangan hak
dan kewajiban, melakukan
kegiatan kemanusiaan,donor
darah, menyantuni anak
yatim, kebenaran dan
keadilan taat hukum dan
tidak diskriminatif.

Implementasi sila ketiga, persatuan Indonesia, menghendaki kepentingan negara di atas kepentingan pribadi dan golongan, berkorban; bekerja keras dan membayar pajak, cinta tanah air, meningkatkan prestasi di segala bidang, bangga sebagai BangsaIndonesia; berani dan percaya diri sebagai warga negara Indonesia.

Implementasi sila keempat, kerakyatan yang dipimpin oleh hikmat kebijaksanaan dalam

permusyawaratan/perwakila $\mathrm{n}$ menghendaki masyarakat harus mengawasi wakil rakyat, hasil musyawarah harus diterima dan dilaksanakan dengan tanggungjawab.

Implementasi sila kelima, keadilan sosial bagi seluruh rakyatIndonesiamenghenda ki perbuatan luhur; saling membantu dan gotong royong, adil; tidak pilihkasih, menghormati orang lain; tidak menghalangi orang lain, suka memberi pertolongan; tidak egois dan individual, bekerja keras, menghargai karya orang lain; tidak membajak".

Implementasi tersebut

berdasarkan runutan yang

diuraikan secara tegas oleh

Soekarno. Nasionalisme

(kebangsaan) sebagai prinsip

pertama diimbangi oleh prinsip

yang kedua (kemanusiaan) agar

Indonesia tidak terjerumus ke

dalam chauvinisme sempit.

Mufakat (prinsip yang ketiga)

bukan demi kemenangan paham

itu sendiri, melainkan demi

mewujudkan keadilan sosial

(prinsip yang keempat), dan

terakhir ketuhanan dipakai

sebagai prinsip yang terakhir

sebagai pemersatu atas semua

prinsip tersebut karena

keseriusan dengan konsep

tersebut. 
Dalam alur pikir ini tidak mengherankan jika kemudian Soekarno memeras prinsip yang pertama dan kedua menjadi socio-nationalisme, $\quad$ prinsip ketiga dan keempat menjadi socio-democratie, $\quad$ dan Ketuhanan. Ini kemudian yang dinamakannya sebagai Tri-Sila. Tri Sila ini pun kemudian diperasnya ke dalam prinsip gotong-royong (Eka Sila). Mengapa? Karena, pertama: socio-nationalisme

menampakkan dirinya dalam kebersamaan bangsa-bangsa tanpa menghilangkan identitas bangsa (ini adalah satu ciri dari semangat gotong-royong).

Kedua, socio-democratie menampakkan dirinya dalam mufakat bersama demi mencapai kesejahteraan sosial bersama (ini juga ciri gotong-royong). Ketiga, Ketuhanan yang digagas Soekarno adalah ketuhanan yang berkebudayaan yang berarti ketuhanan yang dimiliki oleh Bangsa Indonesia dilandasi dengan semangat toleransi yang bisa menerima keberadaan para pemeluk agama lain. Budaya toleransi inilah ciri khas semangat gotong-royong dari Bangsa Indonesia sejak dulu kala (Dewantara, 2017: 78)

\section{Manusia yang Berketuhanan}

Sila pertama Pancasila yang berbunyi "Ketuhanan Yang Maha Esa" mengandung dua pengertian pokok, yaitu tentang Ketuhanan Yang Maha Esa (pengertian lainnya tentang apa?). Ketuhanan berasal dari 
kata Tuhan, yaitu zat Yang

Maha Kuasa, yang menciptakan alam semesta. Oleh sebab itu, tidak satu pun yang dapat menyamai-Nya.

Secara rinci nilai-nilai

yang terkandung dalam sila

Ketuhanan Yang Maha Esa adalah:

a. Adanya sikap percaya dan takwa kepada Tuhan Yang Maha Esa.

b. Kepercayaan dan ketakwaan terhadap Tuhan Yang Maha Esa sesuai dengan agama dan kepercayaannya menurut dasar kemanusiaan yang adil dan beradab.

c. Mengembangkan sikap hormat-menghormati dan bekerjasama antarpemeluk beragama dan penganut kepercayaan terhadap

Tuhan Yang Maha Esa.

d. Membina kerukunan hidup di antara sesama umat beragama dan penganut kepercayaan terhadap Tuhan Yang Maha Esa.

e. Hubungan antara manusia dengan Tuhan Yang Maha Esa sebagai hak asasi yang paling hakiki.

f. Tiap-tiap penduduk mempunyai kebebasan dalam menjalankan ibadah sesuai dengan agama dan kepercayaannya masingmasing.

g. Tidak memaksakan agama dan kepercayaan kepada orang lain.

h. Tiap-tiap penduduk mempunyai kebebasan dalam menjalankan ibadah 
sesuai dengan agama dan kepercayaannya masingmasing (Notonagoro, 1974: 57).

Sebagai dasar filsafat negara Indonesia nilai-nilai Pancasila telah ada pada Bangsa Indonesia sejak zaman dahulu kala, berupa nilai-nilai adat istiadat, kebudayaan, dan nilainilai agama. Dengan demikian, sila Ketuhanan Yang Maha Esa yang nilai-nilainya telah hidup pada Bangsa Indonesia merupakan kausa materialis (sebab material, seperti yang dijelaskan filsuf Aristoteles). Kausa materialis merupakan produk warisan leluhur yang digali dari nilai budaya bangsa Indonesia. Isi dari warisan leluhur tersebut berupa nilai- nilai askiologis Pancasila yang dijadikan pedoman bagi bangsa Indonesia dalam berperilaku sehari-hari, baik sebagai individu, maupun sebagai anggota masyarakat (2020: 25). Hal ini mengandung makna bahwa negara dengan Tuhan adalah hubungan sebabakibat yang tidak langsung melalui manusia sebagai pendukung pokok negara. Maka sesuai dengan makna yang terkandung dalam sila pertama bahwa adanya Tuhan bagi bangsa dan negara Indonesia telah menjadi suatu keyakinan, sehingga adanya Tuhan bukanlah persoalan melainkan sudah menjadi suatu kenyataan secara objektif (Notonagoro, 1974: 67). 
Prinsip ketuhanan Yang keadilan sosial dan sila persatuan Maha Esa harus dimasukkan ke Indonesia, sehingga mampu dalam Pancasila, karena menurut mewujudkan keadilan dan Soekarno, Bangsa Indonesia pada kemanusiaan yang sempurna. umumnya adalah bangsa yang ber- Sedangkan upaya perwujudannya Tuhan (Rahardjo, 2001: 35). Sudah tertuang dalam sila kerakyatan dari zaman nenek moyang, manusia- sebagai mekanisme politik untuk manusia yang mendiami tanah mencapai tujuan dimaksud.

Indonesia adalah pada umumnya manusia-manusia yang ber-Tuhan. Dengan kata lain, manusia Indonesia, menurut Soekarno, memiliki jiwa, corak karakter, watak, pembawaan, dan kepribadian umum, yakni manusia religius (Aning, 2016: 58).

\section{SIMPULAN}

Pancasila menunjukkan bentuk dari kemanusiaan dalam sila kedua yang menempatkan manusia sebagai tujuan utama pembangunan seperti dijelaskan dalam sila

$$
\text { Pembangunan manusia }
$$

Indonesia dalam

mengimplementasikannya harus dengan langkah konkret yang memiliki kesesuaian dengan falsafah negara, yaitu Pancasila. Hal ini karena pembangunan manusia Indonesia dalam perspektif filsafat Pancasila Soekarno diartikan sebagai pembangunan yang tidak sekedar menekankan pada aspek kebersamaan, kekeluargaan, dan gotong royong, melainkan juga pada 
aspek religiusitas atau aspek

ketuhanan.

\section{DAFTAR PUSTAKA}

Aning, Floriberta (ed). (2016). Filsafat Pancasila Menurut Bung Karno, Yogyakarta: Media Presindo.

Arif, Syaiful. (2016). Falsafah Kebudayaan Pancasila; Nilai dan Kontradiksi Sosialnya. Jakarta: PT. Gramedia Pustaka Utama.

Dewantara, W Agustinus. (2017). Alangkah Hebatnya Negara Gotong Royong (Indonesia dalam Kacamata Soekarno). Yogyakarta: PT. Kanisius.

Notonagoro.(1974). Pancasila Dasar Falsafah Negara Republik Indonesia. Jakarta: Pantjuran Tujuh.

Poespowardojo, S dan Hardjatno, N. J. M. T. (2010). Pancasila sebagai Dasar Negara dan Pandangan Hidup Bangsa. Pokja Ideologi. Jakarta: Lemhannas.

Rahardjo, Iman Toto K. dan W. K, Herdianto (ed). (2001). Bung Karno, Wacana Konstitusi dan Demokrasi: Kenangan 100 Tahun Bung Karno, Jakarta: Grasindo.

Sekretariat Negara Republik Indonesia.(1995)..Risalah Sidang Badan Penyelidik Usaha-Usaha Persiapan
Kemerdekaan Indonesia (BPUPKI). Jakarta: Kementerian Setneg.

Srijanti, A. Rahman, H.I. Purwanto S. K. (2007). Etika Berwarganegara, Pendidikan Kewarganegaraan di Perguruan Tinggi. Jakarta: SalembaEmpat.

UNDP. (2009). Human Development Report 2009.

Hidayat, Ferry. (2018). Pancasila: Perspektif Pendiri RI dan Problematikanya". Koleksi Digital IAIN Palangka Raya.

Mahendra, Putu Ronny Angga dan I Made Kartika . (2020). Memperkuat Kesadaran Bela Negara Dengan Nilai-Nilai Pancasila Dalam Perspektif Kekinian. Jurnal Pendidikan Kewarganegaraan Undiksha Vol. 8 No. 3 (September, 2020). P-ISSN : 2599-2694, E-ISSN : 2599-2686 22.

Rahayu, MH. Sri. (2019). Strategi Membangun Karakter

Generasi Muda yang Beretika Pancasila dalam Kebhinekaan dalam Perspektif Keutuhan Negara Kesatuan Repiblik Indonesia. Jurnal Pendidikan, Volume 28, Nomor 3, Nopember 2019.

Rorong, Michael Jibrael. (2020). Fenomenologi. Yogyakarta : Deepublish Publisher 